OPEN ACCESS

Edited by:

Zerihun Tadele,

University of Bern, Switzerland

Reviewed by:

Henry Wagaba,

National Crops Resources Research

Institute (NaCRRI), Uganda

Jun Fang,

Northeast Institute of Geography and Agroecology, Chinese Academy of

Sciences (CAS), China

*Correspondence: Wilfred Elegba

w.elegba@gaecgh.org; wilfred.elegba@biol.ethz.ch

Hervé Vanderschuren

herve.vanderschuren@kuleuven.be

Specialty section:

This article was submitted to

Plant Breeding,

a section of the journal

Frontiers in Plant Science

Received: 15 February 2021 Accepted: 22 April 2021

Published: 25 May 2021

Citation: Elegba W, McCallum E, Gruissem $W$ and Vanderschuren $H$ (2021) Efficient Genetic Transformation and Regeneration of a Farmer-Preferred

Cassava Cultivar From Ghana.

Front. Plant Sci. 12:668042.

doi: 10.3389/fp/s.2021.668042

\section{Efficient Genetic Transformation and Regeneration of a Farmer-Preferred Cassava Cultivar From Ghana}

\author{
Wilfred Elegba ${ }^{1,2 *}$, Emily McCallum ${ }^{1}$, Wilhelm Gruissem ${ }^{1,3}$ and Hervé Vanderschuren ${ }^{1,4,5 *}$ \\ 'Plant Biotechnology, Institute of Molecular Plant Biology, Department of Biology, ETH Zurich, Zurich, Switzerland, \\ ${ }^{2}$ Biotechnology and Nuclear Agriculture Research Institute, GAEC, Legon, Ghana, ${ }^{3}$ Institute of Biotechnology, National Chung \\ Hsing University, Taichung, Taiwan, ${ }^{4}$ Laboratory of Tropical Crop Improvement, Division of Crop Biotechnics, KU Leuven, \\ Leuven, Belgium, ${ }^{5}$ Plant Genetics, TERRA Research and Teaching Centre, Gembloux Agro BioTech, University of Liège, \\ Gembloux, Belgium
}

Cassava is an important staple crop that provides food and income for about 700 million Africans. Cassava productivity in Africa is limited by viral diseases, mainly cassava mosaic disease (CMD) and cassava brown streak disease (CBSD). Genetic barriers such as high heterozygosity, allopolyploidy, poor seed set, and irregular flowering constrain the development of virus-resistant cassava varieties via conventional breeding. Genetic transformation represents a valuable tool to circumvent several challenges associated with the development of virus resistance and other valuable agronomic traits in cassava. The implementation of genetic transformation in many local African cultivars is limited either by the difficulty to produce friable embryogenic callus (FEC), low transformation, and/or regeneration efficiencies. Here, we report the successful induction of organized embryogenic structures (OES) in 11 farmer-preferred cultivars locally grown in Ghana. The production of high quality FEC from one local cultivar, ADI 001, facilitated its genetic transformation with high shoot regeneration and selection efficiency, comparable to the model cassava cultivar 60444 . We show that using flow cytometry for analysis of nuclear ploidy in FEC tissues prior to genetic transformation ensures the selection of genetically uniform FEC tissue for transformation. The high percentage of single insertion events in transgenic lines indicates the suitability of the ADI 001 cultivar for the introduction of virus resistance and other useful agronomic traits into the farmer-preferred cassava germplasm in Ghana and Africa.

Keywords: cassava, organized embryogenic structures, friable embryogenic callus, shoot regeneration, farmer-preferred cultivars, flow cytometry, genetic transformation

\section{INTRODUCTION}

Nearly 850 million people living in the tropics depend on the starchy storage roots of cassava (Manihot esulenta Crantz) as an important source of carbohydrates in their diet or as raw material in several industries (FAO, 2013). In Africa, cassava is cultivated mainly by smallholder farmers because the crop produces appreciable yields under a wide range of environmental conditions (Ceballos et al., 2004; El-Sharkawy, 2006; Burns et al., 2010). Cassava production in 
Africa is constrained by weeds, drought, pests, and most importantly, viral diseases (Patil and Fauquet, 2009; Vandegeer et al., 2013; Legg et al., 2015; Ekeleme et al., 2019; Orek et al., 2020). Cassava mosaic disease (CMD) and cassava brown streak disease (CBSD) are the two most prevalent viral diseases limiting cassava production in Africa (Legg et al., 2011; Patil et al., 2015; Rey and Vanderschuren, 2017). Conventional breeding approaches to develop virus resistant cassava varieties are lengthy and constrained by high genome heterozygosity, irregular flowering, and low seed set (Jennings and Iglesias, 2002; Kawano, 2003; Ceballos et al., 2004; Nassar, 2010; Bull et al., 2017). Despite these limitations, molecular breeding of cassava has led to the identification of different sources of resistance such as CMD1, which is conferred by polygenic recessive genes (Fregene et al., 1997), the single dominant monogenic gene, CMD2 (Akano et al., 2002; Fregene et al., 2006; Rabbi et al., 2014), and CMD3 (Okogbenin et al., 2012).

Genetic transformation can complement traditional or molecular breeding approaches in developing cassava varieties with engineered improved traits such as virus resistance, amylosefree starch, increased micronutrient content, reduced cyanogen content, and micronutrient composition (Siritunga and Sayre, 2003; Jorgensen et al., 2005; Zhang et al., 2005; Vanderschuren et al., 2009, 2012, 2014; Liu et al., 2011; Li et al., 2015; Bull et al., 2018; Narayanan et al., 2019, 2020). Genetic transformation is also a key step in the development of transgene-free genome edited cassava as recently demonstrated by the transformation of cassava with an expression cassette containing genes for Cas9, guide-RNA, and Arabidopsis FLOWERING LOCUS T for early flowering, which was subsequently segregated out by a genetic cross under greenhouse conditions (Bull et al., 2018; Zaidi et al., 2019).

Genetic transformation of cassava requires suitable target tissues for successful recovery of transformed plants. To date, somatic embryo cotyledons (Luong et al., 1995; Li et al., 1996; Zhang et al., 2000; Ihemere et al., 2006), embryogenic suspension cultures (Schöpke et al., 1993, 1996; González et al., 1998; Schreuder et al., 2001), and friable embryogenic callus (Taylor et al., 1996; Bull et al., 2009; Zainuddin et al., 2012; Chetty et al., 2013; Nyaboga et al., 2013) have been transformed successfully. However, challenges such as genotype-dependent production of friable embryogenic callus (FEC), low regeneration rates from transformed calli or low conversion of somatic embryos into plants have also been reported (Schöpke et al., 1996; Baba et al., 2008; Liu et al., 2011; Zainuddin et al., 2012; Nyaboga et al., 2013; Lentz et al., 2018).

Friable embryogenic calli are now mostly used for cassava transformation because the tissue is suitable for large production of independent transgenic events with various cultivars, and particularly the model cultivar 60444 (Schreuder et al., 2001; Bull et al., 2009; Taylor et al., 2012; Chetty et al., 2013). FEC tissue reduces the risk of generating chimeric plants because regenerating plantlets originate from individual transformed cells (Taylor et al., 1996, 2012; González et al., 1998; Bull et al., 2009; Zainuddin et al., 2012; Nyaboga et al., 2013, 2015). A major challenge of FEC-based cassava transformation is the generation of FEC suitable for transformation of local cultivars or landraces. Induction of FEC tissue is genotype-dependent and requires optimization for each cultivar (Raemakers et al., 2001; Rossin and Rey, 2011; Zainuddin et al., 2012; Chetty et al., 2013; Nyaboga et al., 2013, 2015; Lentz et al., 2018). Moreover, potential genome instability and changes in gene expression following embryogenesis (Ma et al., 2015), or the loss of resistance to CMD during tissue culture (Beyene et al., 2016a; Chauhan et al., 2018), necessitate protocol modifications for different cultivars.

Induction of high quality FECs using the protocol established by Bull et al. (2009) has been successful for the African farmeror industry-preferred cassava landraces TME3, TME7, TME204, TME14, T200, Ebwanatereka, Kibandameno, and Serere (Bull et al., 2009; Zainuddin et al., 2012; Chetty et al., 2013; Nyaboga et al., 2013, 2015). Following initial efforts to adapt the protocol for the transformation of farmer-preferred genotypes mainly from Africa (Taylor et al., 2012; Nyaboga et al., 2013; Chauhan et al., 2015; Beyene et al., 2016b), expanding transformation to other farmer-preferred landraces across Africa is needed for adoption of transgenic technologies. It is important to enable transgenic technologies for each region of Africa by establishing protocols for cultivars that have been selected by farmers for improved traits and adaptation to local environments (Fregene et al., 2000; Vanderschuren, 2012). The induction of high quality FEC tissues suitable for transformation from a broad range of African cassava genotypes is critical for the development and deployment of cultivars with resistance to cassava mosaic geminiviruses (CMGs) and cassava brown streak viruses (CBSVs) across Africa. More importantly, it is key to establish robust genetic transformation protocols that can be implemented in African laboratories (Vanderschuren, 2012; Chetty et al., 2013; Nyaboga et al., 2013; Ojola et al., 2018; Walsh et al., 2019).

Here, we report the successful induction of organized embryogenic structures (OES) in 11 farmer-preferred cultivars locally grown in Ghana. The production of high quality FEC suitable for genetic transformation was achieved in one local cultivar, ADI 001. The efficiencies of FEC induction, genetic transformation and regeneration in transformed tissues of ADI 001 were comparable to the model cultivar, 60444 . Our protocol for genetic transformation of a local cassava cultivar can help to expand transformation capacity to other locally adapted cassava cultivars in Africa and to facilitate crop biotechnology capacities in African laboratories.

\section{MATERIALS AND METHODS}

\section{Plant Material}

Eleven cassava genotypes representative of the varieties cultivated by farmers in Ghana (Afisiafi, Ankra, ADI 001, Bosomnsia, Dagarti, IFAD, Megyewontem, Nkabom, Santum, Tomfa, and Tuaka) were obtained from the in vitro cassava library of the Biotechnology and Nuclear Agriculture Research Institute (BNARI), Ghana. The model cultivar, 60444 was obtained from the in vitro germplasm collection of the Plant Biotechnology Laboratory at ETH Zurich. All plant material was maintained 
in vitro on cassava basic medium (CBM) media containing Murashige and Skoog (MS) basal salts with vitamins (Duchefa Biochemie, RV Haarlem, Netherlands), $20 \mathrm{~g} \mathrm{~L}^{-1}$ sucrose (Roth, Switzerland), $2 \mathrm{mM} \mathrm{CuSO}_{4}$ (Sigma-Aldrich, Munich, Germany), $3 \mathrm{~g} \mathrm{~L}^{-1}$ Gelrite (Duchefa Biochemie, RV Haarlem, Netherlands), and $50 \mu \mathrm{g} \mathrm{ml}^{-1}$ carbenicillin (Duchefa Biochemie, RV Haarlem, Netherlands) at $28^{\circ} \mathrm{C}, 16 / 8 \mathrm{~h}$ light/dark regime in growth cabinets.

\section{Induction and Proliferation of Organized Embryogenic Structures and Friable Embryogenic Callus}

Organized embryogenic structures and FEC induction was initiated in Ghanaian cassava cultivars according to the protocol established by Bull et al. (2009) as briefly summarized here. For OES induction, stem cuttings (ca. $5 \mathrm{~mm}$ long) from 4 weeks old in vitro plants were placed horizontally on axillary bud enlargement medium (CAM) for 2-4 days (Zhang and Gruissem, 2004; Bull et al., 2009; Zainuddin et al., 2012). Enlarged axillary buds were isolated with a sterile syringe needle and transferred to OES induction medium (CIM). Plates were kept in the dark for 14 days and explants transferred to fresh CIM plates. OES induction and multiplication was carried out on CAM containing MS basal medium containing 6-benzylaminopurne (BAP; $10 \mathrm{mg} \mathrm{L}^{-1}$ ). For multiplication, OES were transferred to MS basal medium containing $12 \mathrm{mg} \mathrm{L}^{-1}$ 4-amino-3, 5, 6-trichloro-2-pyridinecarboxylic acid (picloram). Thirty-six explants per cultivar were assessed on picloram-containing medium and experiments were repeated four times.

For induction of FECs, OES generated from the selected cultivars on CIM media were transferred to Gresshoff and Doy (GD) medium (Duchefa Biochemie, RV Haarlem, Netherlands; Gresshoff and Doy, 1974) containing $12 \mathrm{mg} \mathrm{L}^{-1}$ picloram. OES were transferred to fresh GD media every 21 days (up to a maximum of six transfer stages; GD1-GD6). Similarly, any FEC material formed from OES was transferred every 21 days to fresh GD media for further multiplication and selection of quality friable embryogenic tissue.

To improve FEC induction in farmer-preferred cassava cultivars, we replaced the auxin picloram in the CIM media with another synthetic auxin, 2,4-dichlorophenoxyacetic acid (2, 4-D; Duchefa Biochemie, RV Haarlem, Netherlands) at a concentration of $8 \mathrm{mg} \mathrm{L}^{-1}$. After 4 days of incubation on CAM medium, swollen axillary buds were excised and transferred to CIM media supplemented with $8 \mathrm{mg} \mathrm{L}^{-1}$ 2,4-D. Any OES tissues formed were transferred to GD medium supplemented with $8 \mathrm{mg} \mathrm{L}^{-1}$ 2,4-D. OES were transferred to fresh GD media up to a maximum of six transfer stages; GD1-GD6. This experiment was repeated twice with a minimum of 48 explants per cultivar (six plates with eight explants per plate) used for each experiment. In both experiments, OES tissues from picloram and 2,4-D were kept separate at the different stages (CAM, CIM, and GD stages).

\section{Ploidy Analysis of FECs Induced From Ghanaian Cassava Cultivar, ADI 001}

An Otto buffer protocol with 4',6-diamidino-2-phenylindole (DAPI) staining adapted for cassava FEC tissues was used to measure ploidy levels. Specifically, a small sample of FECs was collected from at least three clusters per plate and three plates for each cultivar. FECs were transferred into wells of a 96-well Micronic plate (Lelystad, Netherlands). Two TOMY SUB-30 beads (Adolf Kuhner, Switzerland) and $300 \mu \mathrm{l}$ of Otto I buffer $(0.1 \mathrm{M}$ citric acid, $0.5 \%$ Tween-20) was added to each well. Tissues were ground using a Retsch mill MM301 (Retsch $\mathrm{GmbH}$, Switzerland) for $15 \mathrm{~s}$ at 12.5 revolutions per minute (rpm). As much supernatant as possible was transferred to a 25-30 $\mu \mathrm{M}$ UNIFILTER ${ }^{\circledR}$ plate $\left(\right.$ Whatman $\left.^{\circledR}\right)$ and centrifuged immediately for $10 \mathrm{~s}$ at $1000 \mathrm{rpm}$. Around $100 \mu \mathrm{l}$ of filtrate was transferred to a 96-well plate and $100 \mu \mathrm{l}$ Otto II buffer (0.6 M hydrogen phosphate, with $12 \mu \mathrm{g} \mathrm{ml}{ }^{-1}$ DAPI added immediately before use) was added to each well. Samples were pipetted gently up and down to mix thoroughly and then analyzed with a CytoFLEXS flow cytometer (Beckman Coulter).

\section{Regeneration of Wild-Type ADI 001 FECs}

The regeneration potential of wild-type FECs induced from ADI 001 and 60444 was measured using five plates per cultivar consisting of six FEC clusters. FEC clusters were transferred to embryo maturation and regeneration medium (MSN) containing $1 \mathrm{mg} \mathrm{L}^{-1}$ naphthalene acetic acid (NAA) and $250 \mathrm{mg}$ $\mathrm{L}^{-1}$ carbenicillin (MSN $+\mathrm{C} 250$ ) as previously described by Bull et al. (2009). FEC clusters were transferred to fresh MSN media every 10-14 days for four successive cycles (MSN1MSN4). Maturing cotyledon embryos at MSN 4 stage were counted and transferred to cassava shoot elongation medium (CEM) containing $100 \mathrm{mg} \mathrm{L}^{-1}$ carbenicillin (CEM + C100). After 3 weeks on CEM, well-developed shoots were counted and transferred to $\mathrm{CBM}$ containing $50 \mathrm{mg} \mathrm{L}^{-1}$ carbenicillin for shoot establishment. The regeneration potential was measured as the total number of plants regenerated over 80 days.

\section{Binary Vectors and Agrobacterium Inoculum}

A binary vector, pRNAi-dsAC1 described by Vanderschuren et al. (2009), hereafter referred to as "pCAMBIA-based vector," was transformed into Agrobacterium tumefaciens strain LBA4404 via electroporation. Agrobacterium suspension cultures were prepared according to Bull et al. (2009). Briefly, single Agrobacterium colonies carrying the aforementioned plasmid was transferred from Luria broth (LB) plates containing kanamycin $\left(50 \mathrm{mg} \mathrm{L}^{-1}\right)$, rifampicin $\left(50 \mathrm{mg} \mathrm{L}^{-1}\right)$, and streptomycin (100 $\mathrm{mg} \mathrm{L}^{-1}$ ) and used to inoculate $5 \mathrm{ml}$ liquid LB cultures containing the same antibiotics. Cultures were grown overnight at $28^{\circ} \mathrm{C}$ on a shaker at $200 \mathrm{rpm}$ until an optical density (OD) 600 between 0.7 and 1 was reached. Around $5 \mathrm{ml}$ of the starter culture was used to inoculate $25 \mathrm{ml}$ of $\mathrm{LB}$ culture containing antibiotics and grown overnight at $28^{\circ} \mathrm{C}$ and $200 \mathrm{rpm}$ until $\mathrm{OD}_{600}=0.7-1$. Suspensions were centrifuged at $4,000 \mathrm{~g}$ for $10 \mathrm{~min}$ at room temperature, the supernatant discarded and pellet washed with GD liquid medium. This process was repeated and the bacterial pellet re-suspended in GD medium and diluted to an $\mathrm{OD}_{600}=0.5$. Acetosyringone was added to the suspension to a final concentration of $200 \mu \mathrm{M}$. 


\section{Genetic Transformation, Regeneration, and Screening of Transgenic Plants}

For each cultivar, five FEC plates (each plate contains six FEC clusters) were inoculated with Agrobacterium carrying the pCAMBIA-based binary vector. FECs were co-cultivated with Agrobacterium suspension for 3 days at $24^{\circ} \mathrm{C}$ with $16 / 8 \mathrm{~h}$ light/ dark photoperiod. Co-cultivated FECs were gently scraped from plates into a $50 \mathrm{ml}$ sterile Falcon tube (Sarstedt, Germany) and washed several times with GD solution containing $500 \mathrm{mg}$ $\mathrm{L}^{-1}$ carbenicillin until the supernatant was clear. FECs were transferred to mesh and briefly dried on filter paper before transfer to solid GD media containing $250 \mathrm{mg} \mathrm{L}^{-1}$ carbenicillin (C250) for 4 days. Thereafter, FECs were transferred with the mesh to fresh GD medium containing $\mathrm{C} 250$ and $5 \mathrm{mg} \mathrm{L}^{-1}$ hygromycin. After 7 days, FECs were transferred to GD media containing C250 and increasing concentrations of hygromycin (8 and $15 \mathrm{mg} \mathrm{L}^{-1}$ ) at weekly intervals.

For regeneration, matured FEC tissues were transferred to regeneration medium (MSN + C250) containing $15 \mathrm{mg} \mathrm{L}^{-1}$ hygromycin. Weekly transfer of FEC tissues to freshly prepared regeneration medium was carried out for six successive cycles (MSN1-MSN6). Developing green cotyledons at each MSN stage were counted and transferred to CEM+C100 media. After 3 weeks, well-developed shoots were excised from cotyledons and transferred to CBM + C50 for shoot establishment.

Screening of fully developed plantlets was performed by transferring stem cuttings to CBM media containing $50 \mathrm{mg}$ $\mathrm{L}^{-1}$ carbenicillin and $10 \mathrm{mg} \mathrm{L}^{-1}$ hygromycin (rooting test). The total number of plants positive for the rooting test was counted. Regeneration in transformed tissues was measured as the total number of plants regenerated over 100 days.

\section{Molecular Characterization of Transgenic Lines}

Cassava genomic DNA was extracted from flash frozen leaves using the modified cetyltrimethyl ammonium bromide (CTAB) method (Doyle, 1990). PCR analysis was carried out to confirm integration of a $152 \mathrm{bp}$ region of the $\mathrm{AC} 1$ gene in regenerated plants of ADI 001 and 60444. PCR thermal cycle conditions used were as follows: Initial denaturation for $20 \mathrm{~s}$ at $95^{\circ} \mathrm{C}$, 35 cycles of denaturation for $3 \mathrm{~s}$ at $95^{\circ} \mathrm{C}$, annealing for $15 \mathrm{~s}$ at $60^{\circ} \mathrm{C}$, extension for $30 \mathrm{~s}$ at $72^{\circ} \mathrm{C}$ and final extension for $5 \mathrm{~min}$ at $72^{\circ} \mathrm{C}$. PCR products were resolved on $1 \% \mathrm{w} / \mathrm{v}$ agarose gel and images recorded using a Gel iX20 imager gel documentation system (INTAS science imaging system, Goettingen, Germany).

For Southern blot analysis, aliquots of $15 \mu \mathrm{g}$ DNA were digested with the restriction enzyme, HindIII (Thermo Scientific, Switzerland) and products separated on a $1 \% \mathrm{w} / \mathrm{v}$ agarose gel. Transfer of digested products to nylon membrane (Hybond$\mathrm{N}+$; Amersham Pharmacia Biotech) was performed overnight and hybridization with probes specific for the hygromycin phosphotransferase II (hptII) gene was carried out (Vanderschuren et al., 2009; Zainuddin et al., 2012). Probes were prepared by PCR amplification of a 978 base pair (bp) amplicon of the hygromycin gene and DIG-dUTP labeled using a PCR DIG probe synthesis kit (Roche Diagnostics GmbH, Germany) according to the manufacturer's instructions. Primers used for PCR screening and amplification of the probe for Southern blot are listed in Supplementary Table 1.

\section{Data Analysis}

Data for all parameters except plant regeneration efficiencies in wild-type and transgenic 60444 and ADI 001 FEC tissues was analyzed using GraphPad Prism version 7 (San Diego, United States). Shoot regeneration efficiencies were analyzed using Minitab version 18 (Pennsylvania, United States). All data was subjected to ANOVA and statistically significant results at the 5\% level were eith2er compared with Tukey's or Šidák's multiple comparisons tests.

\section{RESULTS AND DISCUSSION}

\section{Selection of Farmer-Preferred Cultivars and Induction of Organized Embryogenic Structures}

In Africa, preference for traits such as high yield, good cooking quality, early maturity, weed suppression, and resistance to pest and disease influence cultivar adoption by farmers (Hahn et al., 1989; Manu-Aduening et al., 2006). We selected 11 cassava cultivars or landraces popular with farmers in Ghana (Table 1). These cultivars have varying degrees of susceptibility to CMD and CBSD (Elegba et al., 2020). We screened the selected cultivars for production of OES, a critical initial step required for the induction of FEC and subsequent genetic transformation. In cassava, induction of somatic embryogenesis (SE) is genotypedependent and some cultivars, and in particular African cultivars, lose embryogenic competence prior to formation of somatic embryos (Konan et al., 1994; Atehnkeng et al., 2006). Variations in cultivar response to SE have been reported for South American cultivars (Ihemere, 2003). SE has been previously established for two Ghanaian cultivars, ADI 001 and Nkabom, using young leaf lobe explants (Danso et al., 2010). We used axillary meristems as starting material because of the higher efficiency of OES production and reduced production of non-embryogenic callus compared to leaf lobe explants (Taylor et al., 2012; Nyaboga et al., 2015). After 14 days on CIM media, OES were induced from axillary buds in all 11 Ghanaian cassava cultivars on picloram-containing media (Figures 1A-D). OES production in the model cultivar 60444 was significantly higher $(p \leq 0.05)$ compared to Ghanaian cassava cultivars except for Santum $(p=0.06$; Table 1; Supplementary Table 2). In contrast, there was no significant difference in OES production frequency between 60444 and Ghanaian cassava cultivars on 2,4-D-containing media (Table 1; Supplementary Table 3). With the exception of Tuaka and Bosomnsia that failed to form OES on 2,4-D-containing media in two independent experiments, we noticed that OES production was significantly higher $(p \leq 0.05)$ on 2,4 -D-containing medium compared to picloram-containing medium in 60444 and all Ghanaian cassava cultivars tested except Santum (Table 1; Supplementary Table 4). However, on 2,4-D containing media, 
TABLE 1 | Agronomic traits, qualities, and average frequency of organized embryogenic structure (OES) production in selected Ghanaian cassava cultivars.

\begin{tabular}{|c|c|c|c|c|}
\hline \multirow[t]{2}{*}{$\begin{array}{l}\text { Cassava } \\
\text { cultivar }\end{array}$} & \multirow[t]{2}{*}{ Agronomic traits } & \multirow[t]{2}{*}{ Status } & \multicolumn{2}{|c|}{$\begin{array}{l}\text { OES frequency } \\
(\%) \pm \mathrm{SE}^{\mathrm{a}}\end{array}$} \\
\hline & & & Picloram ${ }^{b}$ & $2,4-D^{c}$ \\
\hline 60444 & Model cultivar & $\begin{array}{l}\text { Released } \\
\text { variety }\end{array}$ & $74 \pm 3.42^{a}$ & $86 \pm 3.54^{a}$ \\
\hline ADI 001 & $\begin{array}{l}\text { Early maturing } \\
\text { (6-8 months), mealiness }\end{array}$ & Landrace & $52 \pm 4.99^{b c}$ & $90 \pm 0.00^{\mathrm{ac}}$ \\
\hline Santum & $\begin{array}{l}\text { High starch content, } \\
\text { mealiness }\end{array}$ & $\begin{array}{l}\text { Released } \\
\text { variety }\end{array}$ & $55 \pm 5.32^{a}$ & $56 \pm 3.54^{\mathrm{ad}}$ \\
\hline IFAD & $\begin{array}{l}\text { High dry matter (30\%), } \\
\text { high yield (30-35 t/ha), } \\
\text { CMD tolerant }\end{array}$ & $\begin{array}{l}\text { Released } \\
\text { variety }\end{array}$ & $35 \pm 3.30^{b}$ & $81 \pm 0.00^{a}$ \\
\hline Megyewontem & $\begin{array}{l}\text { Early maturing } \\
\text { (6-8 months) }\end{array}$ & Landrace & $37 \pm 2.99^{b c}$ & $92 \pm 4.95^{\mathrm{ae}}$ \\
\hline Nkabom & $\begin{array}{l}\text { High dry matter (32\%), } \\
\text { high yield (28-32 t/ha), } \\
\text { CMD tolerant }\end{array}$ & $\begin{array}{l}\text { Released } \\
\text { variety }\end{array}$ & $17 \pm 2.16^{\mathrm{bd}}$ & $78 \pm 7.78^{a}$ \\
\hline Tomfa & $\begin{array}{l}\text { Dry matter (29\%), starch } \\
\text { content (58\%), mealiness }\end{array}$ & $\begin{array}{l}\text { Released } \\
\text { variety }\end{array}$ & $42 \pm 5.29^{\text {be }}$ & $84 \pm 4.95^{\mathrm{a}}$ \\
\hline Ankra & $\begin{array}{l}\text { High dry matter (34\%), } \\
\text { high starch content } \\
(68 \%), \text { mealiness }\end{array}$ & $\begin{array}{l}\text { Released } \\
\text { variety }\end{array}$ & $31 \pm 1.63^{\mathrm{bd}}$ & $84 \pm 7.78^{a}$ \\
\hline Dagarti & $\begin{array}{l}\text { High dry matter (37\%), } \\
\text { high starch content } \\
(65 \%), \text { CMD tolerant }\end{array}$ & $\begin{array}{l}\text { Released } \\
\text { variety }\end{array}$ & $36 \pm 2.94^{b}$ & $75 \pm 14.14^{a}$ \\
\hline Afisiafi & $\begin{array}{l}\text { High dry matter (32\%), } \\
\text { high yield (28-35 t/ha), } \\
\text { CMD tolerant }\end{array}$ & $\begin{array}{l}\text { Released } \\
\text { variety }\end{array}$ & $37 \pm 5.56^{\text {be }}$ & $79 \pm 2.83^{a}$ \\
\hline Tuaka & $\begin{array}{l}\text { Early maturing } \\
\text { (6-8 months), dry matter } \\
(23 \%)\end{array}$ & Landrace & $12 \pm 2.22^{\mathrm{bce}}$ & $0^{\mathrm{b}}$ \\
\hline Bosomnsia & $\begin{array}{l}\text { Early maturing } \\
\text { (6-8 months), mealiness }\end{array}$ & Landrace & $14 \pm 4.35^{b}$ & $0^{b}$ \\
\hline
\end{tabular}

${ }^{a}$ OES production frequency calculated as ratio of OES clusters/total number of explants expressed as a percentage.

${ }^{b}$ OES frequency on picloram shows means of four independent experiments $\pm S E$.

${ }^{\circ} O E S$ frequency on 2,4-D shows means of two independent experiments $\pm S E$. (Tukey's multiple comparison test, $p \leq 0.05$ ).

d.erepresent significant differences in OES frequencies on picloram and 2,4-D between cultivars (at 95 or $99 \%$ confidence interval difference).

OES tissues produced in Ghanaian cassava cultivars and 60444 looked darker in color compared with picloram-derived tissues by the third cycle on CIM (Figures 1G-L). The highest OES production frequency on picloram and 2,4-D-containing media was recorded in Santum (55\%) and Megyewontem (92\%), respectively (Table 1). This successful production of OES from axillary bud explants in locally adapted cassava cultivars preferred by farmers in Ghana is important for induction of FECs and subsequent genetic transformation.

\section{FEC Induction in Ghanaian Cassava Cultivar ADI 001}

Using the FEC induction protocol optimized for the model cultivar, 60444, we first tested the 11 Ghanaian farmer-preferred cassava cultivars for FEC induction and multiplication from OES obtained on picloram-containing medium. After 6 weeks on GD medium containing picloram at $12 \mathrm{mg} \mathrm{L}^{-1}$, OES tissues of 60444 and the Ghanaian cassava cultivar ADI 001 produced
FECs (Figures 1E,F). However, OES tissues in the remaining 10 Ghanaian cultivars failed to form FECs on GD media. After 8 weeks on GD medium, OES became covered by growth of whitish-colored non-embryogenic callus tissue (Figures 1C,D). This observation was confirmed in four independent experiments in which only OES from ADI 001 and 60444 produced FECs.

Friable embryogenic callus induced from OES in ADI 001 were pale yellow in color and showed a good rate of proliferation similar to FEC from 60444 (Figures 1E,F). A major bottleneck for genetic transformation of farmer-preferred cassava cultivars or landraces is the failure to generate FECs from OES as we also found for the selected Ghanaian cultivars and similar to what has been reported for other cassava landraces cultivated in West Africa (Raemakers et al., 2001; Hankoua et al., 2006). Therefore, the protocol reported by Bull et al. (2009) that has been successfully used for FEC production of several cassava cultivars requires further optimization to increase the success of FEC induction in a broad range of cassava cultivars and landraces.

We next tested if OES obtained on 2,4-D-containing medium could improve FEC induction in Ghanaian cassava cultivars (Table 1). We used $8 \mathrm{mg} \mathrm{L}^{-1} 2,4-\mathrm{D}$ as a previously reported optimal concentration for induction of high frequency somatic embryos (Danso and Ford-Lloyd, 2002; Danso et al., 2010). However, we observed a decrease in growth and number of OES by the second cycle on GD medium (GD2) for FEC induction in 60444 and the Ghanaian cultivars we tested (Supplementary Table 5). Only 60444 OES tissues converted to FECs, although at low frequency (Supplementary Table 5). After 8 weeks on GD medium, OES tissues of Ghanaian cultivars turned dark yellow or brown in color and converted to non-embryogenic structures (Figures 1G-L). Therefore, addition of 2,4-D in the FEC induction medium (CIM) seems to favor continuous non-OES cell proliferation instead of conversion to FEC (Taylor et al., 1996). In contrast, as shown above and reported earlier, picloram in combination with GD medium is efficient in the conversion of embryogenic tissues to FECs in cassava (Taylor et al., 1996; Bull et al., 2009; Zainuddin et al., 2012; Chetty et al., 2013; Nyaboga et al., 2013). The exact mechanism of picloram on FEC induction in cassava is not clearly understood. However, initiation of somatic embryogenesis involves a weakening of the cell to cell interaction gradient that coordinates bipolar embryo development (Pretova and Williams, 1986) and it appears picloram is more effective compared to 2,4-D at stimulating the weakening process. The upregulation of cell cycle related genes and several genes involved in brassinosteriod signaling and jasmonate (JA) metabolism, such as polysaccharide hydrolase, are likely to influence cell wall modifications (Nowack et al., 2006; Elhiti et al., 2013; Ma et al., 2015).

\section{Nuclear Ploidy of 7-Month-Old FECs in ADI 001 and 60444 Remains Stable}

Continuous passage of tissues through in vitro culture over time can cause changes such as chromosomal rearrangements or increase in chromosome number and ploidy level, which can result in somaclonal variation and potential phenotype changes in regenerated 

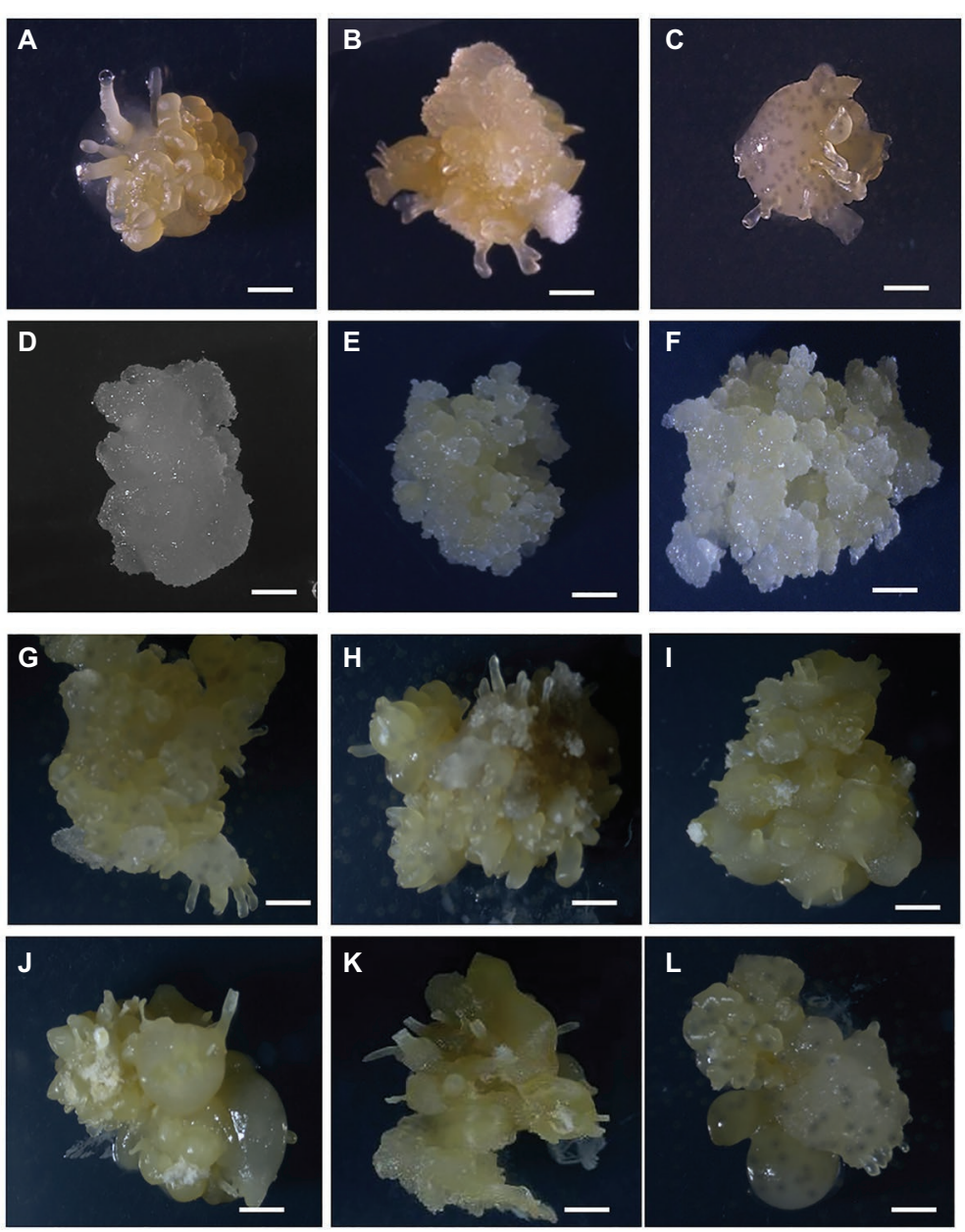

FIGURE 1 | Formation of OES and FEC in Ghanaian cassava cultivars. OES production on CIM media containing picloram (12 mg L-1; A) 60444 , (B) Santum, (C) ADI 001, (D) IFAD. Proliferating FEC tissues in cultivars (E) 60444 and (F) ADI 001. OES production on CIM media containing 2,4-D (8 mg L-1; G), 60444 (H) ADI 001, (I) Ankra, (J) IFAD, (K) Megyewontem, and (L) Nkabom. Bar represents 2 mm.

plants (Kaeppler et al., 2000; Thorpe, 2006; Miguel and Marum, 2011; Stroud et al., 2013; Ma et al., 2015). Morphological changes and decreased regeneration potential have been associated with FECs that have been maintained for long periods of time (i.e., over 6 months) in liquid suspension culture (Raemakers et al., 2001; Ma et al., 2015). Therefore, it is important to include quality control steps during the production and regeneration of embryogenic cassava cells. We assessed the stability of nuclear ploidy of FECs induced from ADI 001 and 60044 using flow cytometry of FEC tissue after 10 successive cycles of subculture (approximately 7-months) on GD medium containing picloram $\left(12 \mathrm{mg} \mathrm{L}^{-1}\right)$. Nuclei from a tomato leaf sample were used as a DNA reference standard. The tomato nuclear genome is $960 \mathrm{Mb}$ and therefore similar in size to the cassava nuclear genome $(750 \mathrm{Mb})$, which minimizes errors resulting from sampling or instrument variation (Vindeløv et al., 1983; Bagwell et al., 1989). Nuclei from a cassava leaf sample of 60444 were calibrated against the reference tomato standard to confirm diploid genome status.

Analysis of the flow cytometry profiles of nuclei isolated from several independent FEC clumps of ADI 001 showed one dominant peak equivalent to the diploid 60444 leaf nuclei reference (Figure 2A). Similarly, the ploidy profile of FECs induced from 60444 exhibited a single diploid peak (Figure 2B). These results indicate that FECs induced from ADI 001 and 60444 have mainly nuclei with diploid genomes even after 10 cycles of subculture on picloram-containing medium.

Building robust platforms for genetic transformation of a broad range of cassava cultivars requires routine induction of OES and FEC, and regeneration of transformed plants through somatic embryogenesis. We suggest that integrating flow cytometry analysis of nuclear genome ploidy into the FEC induction and genetic transformation pipeline ensures reliable FEC ploidy stability at the early stages of FEC multiplication for transformation. This avoids the regeneration of plants from polyploid somatic embryos that produce not true-to-type plants with phenotypic changes such as thicker stems, variation in leaf anatomy, longer petiole, and internodal distances (Awoleye et al., 1994; Taylor et al., 2004; Nassar et al., 2008), which is often manifested only during later stages of plant regeneration and growth. 


\section{Regeneration of Plants From Picloram- Induced Wild-Type FECs}

Genotypes also determine the regeneration efficiency of cassava cultivars (Raemakers et al., 2001; Ihemere, 2003; Hankoua et al., 2005; Atehnkeng et al., 2006; Zainuddin et al., 2012; Chetty et al., 2013; Nyaboga et al., 2013). Therefore, testing the shoot regeneration efficiency of FECs produced from local landraces or farmer-preferred cassava cultivars is important to ensure the production of whole plants from explants is feasible.

We evaluated the regeneration potential of wild-type ADI 001 FECs in comparison to 60444 (Figure 3). Cotyledon regeneration in ADI 001 (Figures $\mathbf{3 A - C}$ ) was observed after
10 days on MSN1 media compared to 12 days for 60444 (Figures 3D-F). The number of embryos progressing into cotyledon stages in ADI 001 and 60444 increased significantly $(p \leq 0.05)$ after 20 days on embryo maturation and regeneration medium (Supplementary Figure 1; Supplementary Table 6). At 40 days after transfer of embryos to maturation medium, there was no significant difference $(p=0.824)$ in the total number of regenerated cotyledons from wild-type FECs of ADI 001 (Figures 3G,H) and 60444 (Table 2; Supplementary Table 7). We recovered from 30 FEC clumps 160 cotyledon-stage embryos from ADI 001 and 150 cotyledonstage embryos from 60444 . The number of whole plants that
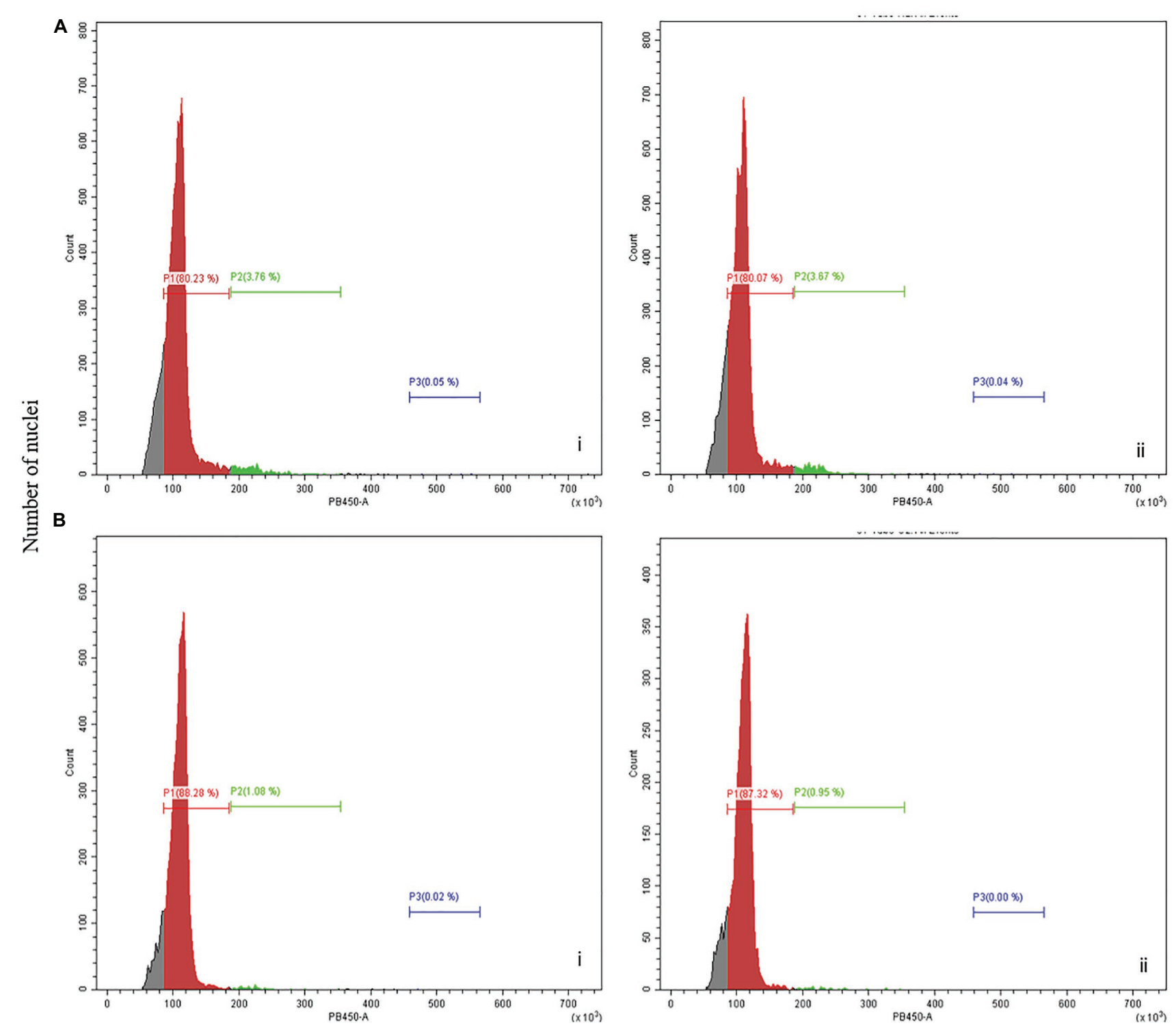

Relative fluorescence

FIGURE 2 | Flow cytometry analysis of picloram-induced FECs. Flow cytometry analysis showing relative fluorescence intensity of FECs induced in cassava cultivar (A) ADI 001 and (B) 60444. Biological replicates, $n=2$ (indicated by i and ii) are shown for panels (A,B). Each histogram shows the nuclear DNA level for each clump of FEC sampled, $n=3$. 
regenerated from wild-type cotyledon-stage embryos was similar ( $p=0.729$ ) between 60444 and ADI 001 (Supplementary Table 7). Plants regenerated from ADI 001 FECs looked normal (Figure 3I). Together, our results indicate that the Ghanaian cassava cultivar ADI 001 performs equally well as 60444 with respect to FEC induction and regeneration. The high plant regeneration efficiency that we achieved in ADI 001 (above $60 \%$ ) indicates that this cultivar may also allow for high transformation capacity.

\section{Efficient Genetic Transformation of Ghanaian Farmer-Preferred Cassava Cultivar ADI 001}

Following the evaluation of the ADI 001 regeneration capacity, we tested the transformability of this Ghanaian cultivar. To determine the transformation efficiency of ADI 001, we transformed 60444 and ADI 001 FEC tissues using a pCAMBIA-based vector carrying a hairpin construct against the GMS AC1 gene that had been previously transformed successfully (Vanderschuren et al., 2009). After five weekly transfers of FEC tissues on embryo maturation and regeneration media containing $250 \mathrm{mg} \mathrm{L}^{-1}$ carbenicillin and $15 \mathrm{mg} \mathrm{L}^{-1}$ hygromycin, the total number of regenerated cotyledons and plants from transgenic FECs of ADI 001 was not significantly different compared to 60444 (Table 3; Supplementary Table 8). Plant regeneration efficiency in the local cultivar, ADI 001 (58\%) was comparable to 60444 (65\%; Table 3).
Rapid and efficient screening of regenerating potential in transgenic plantlets is an important step to identify plants with a T-DNA insertion in the genome, thereby reducing the number of transgenic plants for subsequent molecular characterization. To assess the efficiency of Agrobacterium-mediated transformation of the ADI 001 genotype and to identify transformed plantlets, we used a rooting test, which is efficient for identification of transgenic cassava plants (Zhang and Puonti-Kaerlas, 2000; Bull et al., 2009; Zainuddin et al., 2012). In the rooting test, hygromycinresistant transgenic cassava shoots produce roots and leaves on hygromycin-containing media $(\mathrm{CBM}+\mathrm{C} 50+\mathrm{H} 10)$, indicating successful integration of the T-DNA carrying the hptII gene into the genome. Almost $90 \%$ of the regenerated ADI 001 plantlets were positive for the rooting test compared to $56 \%$ of the 60444 regenerated plantlets (Supplementary Table 9). Although, we only performed and characterized the transformation with a single batch of ADI 001 FEC, the good selection efficiency of transgenic ADI 001 plantlets suggests that this cultivar is amenable to genetic transformation. In order to confirm integration of the T-DNA cassette into the cassava genome, we screened by PCR a selected number of ADI 001 plants that were positive in the rooting test (Supplementary Figure 2).

We subsequently determined the number of independent transgenic events using Southern blot analysis on rooting test positive transgenic ADI 001 and 60444 plantlets. Transgene integration was detected in all transgenic lines screened for ADI 001 and 60444 (Supplementary Figure 3). Based on
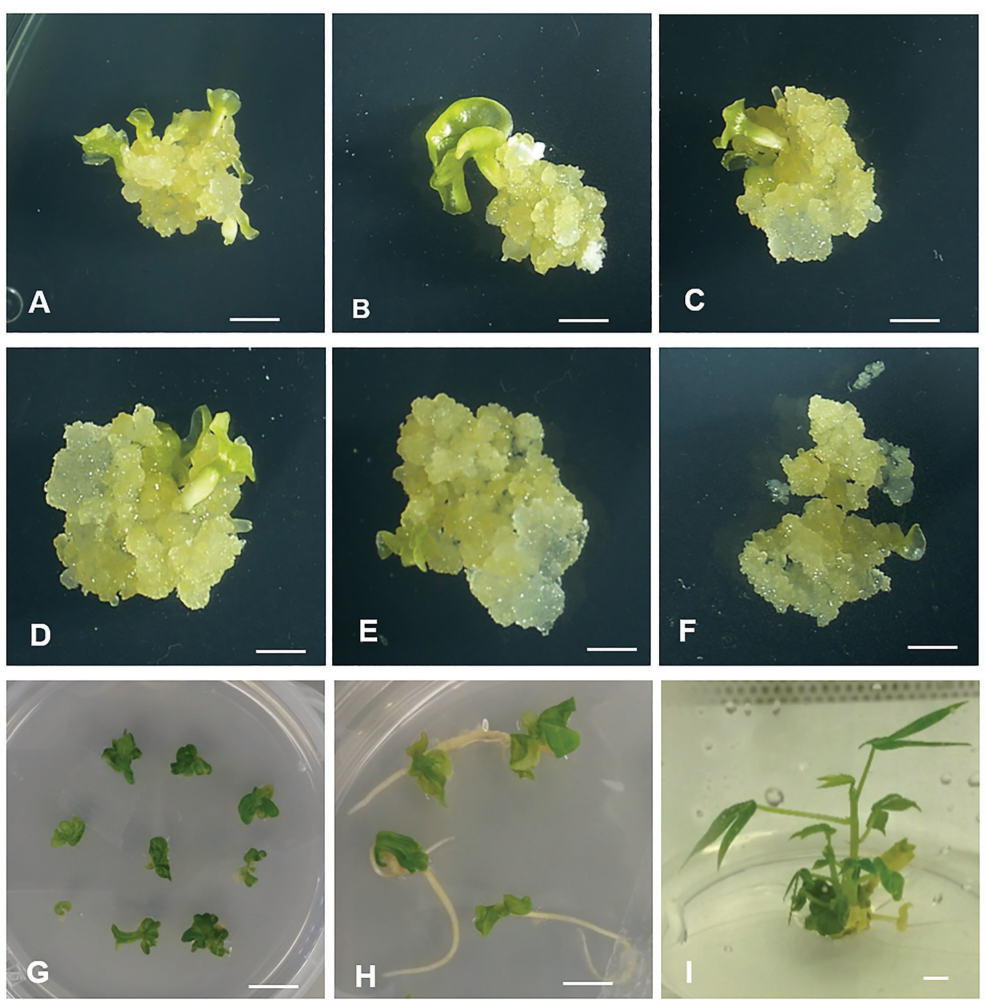

FIGURE 3 | Whole plant regeneration from picloram-induced wild-type FECs of ADI 001 and 60444. Embryo emergence in ADI (A-C) and 60444 (D-F). Cotyledon development $\mathbf{( G , H )}$ and whole plant regeneration $\mathbf{( I )}$ in wild-type ADI 001 FECs. Bars represents $2 \mathrm{~mm}(\mathbf{A}-\mathbf{H})$ and $1 \mathrm{~mm}(\mathbf{I})$. 
TABLE 2 | Plant regeneration from wild-type ADI 001 and 60444 friable embryogenic callus (FEC) tissues.

\begin{tabular}{lccc}
\hline Cultivar & $\begin{array}{c}\text { No. of regenerated } \\
\text { cotyledons }^{\mathbf{a}}\end{array}$ & $\begin{array}{c}\text { No. of regenerated } \\
\text { plants }\end{array}$ & $\begin{array}{c}\text { Plant regeneration } \\
\text { efficiency }^{\mathbf{b}} \mathbf{( \% )}\end{array}$ \\
\hline 60444 & $150^{\mathrm{a}}$ & $107^{\mathrm{a}}$ & 71 \\
ADI 001 & $160^{\mathrm{a}}$ & $97^{\mathrm{a}}$ & 61 \\
\hline
\end{tabular}

${ }^{a}$ Total number of cotyledons regenerating on embryo maturation media [MSN+C250 + $1 \mathrm{mg}$ $L^{-1}$ naphthalene acetic acid (NAA)] from 30 FEC clusters (five plates; six clusters per plate). ${ }^{b}$ Total number of plants regenerated on cassava basic medium (CBM) media/total number of regenerated cotyledons. Values in a column followed by the same letters are not significantly different from each other at $p \leq 0.05$ (Tukey's pairwise comparison test).

TABLE 3 | Plant regeneration efficiency in transgenic ADI 001 and 60444 FEC tissues.

\begin{tabular}{lccc}
\hline Cultivar & $\begin{array}{c}\text { No. of regenerated } \\
\text { cotyledons }^{\mathbf{a}}\end{array}$ & $\begin{array}{c}\text { No. of regenerated } \\
\text { plants }\end{array}$ & $\begin{array}{c}\text { Plant regeneration } \\
\text { efficiency }^{\mathbf{~}} \text { (\%) }\end{array}$ \\
\hline 60444 & $88^{\mathrm{a}}$ & $57^{\mathrm{a}}$ & 65 \\
$\mathrm{ADI} \mathrm{001}$ & $134^{\mathrm{a}}$ & $78^{\mathrm{a}}$ & 58 \\
\hline
\end{tabular}

aTotal number of cotyledons regenerating on embryo maturation media (MSN

$+C 250+15 \mathrm{mg} \mathrm{L}^{-1}$ hygromycin) from 30 FEC clusters (five plates; six clusters per plate).

${ }^{b}$ Total number of plants regenerated on CBM media (prior to rooting test)/total number

of regenerated cotyledons. Values in a column followed by the same letters are not

significantly different from each other at $p \leq 0.05$ (Tukey's pairwise comparison test).

the hybridization pattern, all of the 17 transgenic lines screened for ADI 001 and 60444 were independent transgenic events. Because plants with low transgene copy numbers (ideally a single insert) are preferred for use in further characterization and subsequent confined field trials, we calculated the percentage of single insertion events as the number of lines containing a single insert of the transgene. In $60444,47 \%$ of the lines screened by Southern blot had a single transgene insert compared to $65 \%$ of lines screened for ADI 001 (Supplementary Table 10).

\section{CONCLUSION}

Genetic improvement of cassava requires the establishment of robust protocols for routine transformation, especially for local cultivars preferred by African farmers. In the present study, we report successful implementation of the protocol reported by Bull et al. (2009) for induction of high quality FECs in an elite local cassava cultivar from Ghana. Efficient genetic transformation and high plant regeneration from transformed FECs of ADI 001 was comparable to the model cultivar, 60444. However, as observed in the present study, the transfer of transformation capacity to local cultivars with farmer- and industry-preferred traits is limited due to high genotypic influence on the embryogenic process. Thus, to unlock the potential of important African cassava cultivars, it is critical to further work on optimization of the protocol for routine production of FEC tissues amenable to genetic transformation, on a cultivar-by-cultivar basis. Optimization of culture conditions or media composition has led to an improvement in FEC induction and subsequent transformation of several African and Brazilian cultivars (Zainuddin et al., 2012; Nyaboga et al., 2013, 2015; Lentz et al., 2018).
More importantly, transfer of transgenic technologies to laboratories in Africa, such as the Biotechnology and Nuclear Agriculture Research Institute (BNARI) in Ghana, through capacity building as has been accomplished through this work is critical for encouraging and sustaining adoption of transgenic technologies in Africa (Ezezika et al., 2012; Vanderschuren, 2012). The presence of appropriately trained personnel is critical to the establishment and maintenance of transformation platforms for crop improvement in Africa. The establishment of cassava transformation platforms in sub-Saharan Africa opens up opportunities for improvement of other important traits such as extension of shelf life, nutrient content, pest resistance, climate-change resilience as well as serve as a basis for the rapid exploitation of CRISPR-based technologies to enhance food security.

\section{DATA AVAILABILITY STATEMENT}

The original contributions presented in the study are included in the article/Supplementary Material, further inquiries can be directed to the corresponding authors.

\section{AUTHOR CONTRIBUTIONS}

HV, WE, EM, and WG conceived and designed the experiments and reviewed and edited the manuscript. WE and EM performed the experiments. WE, HV, and WG analyzed the data. All authors contributed to the article and approved the submitted version.

\section{FUNDING}

WE was supported by a Swiss Government Excellence $\mathrm{PhD}$ Scholarship for foreign students and a Doctoral Scholarship from ETH Zurich. Research in the laboratories of WG is financially supported by funds from ETH Zurich and the Advanced Plant Biotechnology Center from the Featured Areas Research Center Program within the framework of the Higher Education Sprout Project by the Ministry of Education (MOE) in Taiwan.

\section{ACKNOWLEDGMENTS}

The authors would like to thank the members of the Plant Biotechnology Laboratory, ETH Zurich for advice and discussions. We acknowledge the support of Biotechnology and Nuclear Agriculture Research Institute (BNARI), Ghana for supplying the cassava cultivars and discussions.

\section{SUPPLEMENTARY MATERIAL}

The Supplementary Material for this article can be found online at: https://www.frontiersin.org/articles/10.3389/fpls.2021.668042/ full\#supplementary-material 


\section{REFERENCES}

Akano, O., Dixon, O., Mba, C., Barrera, E., and Fregene, M. (2002). Genetic mapping of a dominant gene conferring resistance to cassava mosaic disease. Theor. Appl. Genet. 105, 521-525. doi: 10.1007/s00122-002-0891-7

Atehnkeng, J., Adetimirin, V. O., and Ng, S. Y. C. (2006). Exploring the African cassava (Manihot esculenta Crantz) germplasm for somatic embryogenic competence. Afr. J. Biotechnol. 5, 1324-1329.

Awoleye, F., van Duren, M., Dolezel, J., and Novak, F. J. (1994). Nuclear DNA content and in vitro induced somatic polyploidization cassava (Manihot esculenta Crantz) breeding. Euphytica 76, 195-202. doi: 10.1007/bf00022164

Baba, A. I., Nogueira, F. C. S., Pinheiro, C. B., Brasil, J. N., Jereissati, E. S., Jucá, T. L., et al. (2008). Proteome analysis of secondary somatic embryogenesis in cassava (Manihot esculenta). Plant Sci. 175, 717-723. doi: 10.1016/j.plantsci.2008.07.014

Bagwell, C. B., Baker, D., Whetstone, S., Munson, M., Hitchcox, S., Ault, K. A., et al. (1989). A simple and rapid method for determining the linearity of a flow cytometer amplification system. Cytometry 10, 689-694. doi: 10.1002/ cyto. 990100604

Beyene, G., Chauhan, R. D., Ilyas, M., Wagaba, H., Fauquet, C. M., Miano, D., et al. (2016b). A virus-derived stacked RNAi construct confers robust resistance to cassava brown streak disease. Front. Plant Sci. 7:2052. doi: 10.3389/fpls.2016.02052

Beyene, G., Chauhan, R. D., Wagaba, H., Moll, T., Alicai, T., Miano, D., et al. (2016a). Loss of CMD2-mediated resistance to cassava mosaic disease in plants regenerated through somatic embryogenesis. Mol. Plant Pathol. 17, 1095-1110. doi: 10.1111/mpp.12353

Bull, S. E., Alder, A., Barsan, C., Kohler, M., Hennig, L., Gruissem, W., et al. (2017). Flowering locus T triggers early and fertile flowering in glasshouse cassava (Manihot esculenta Crantz). Plants 6:22. doi: 10.3390/plants6020022

Bull, S. E., Owiti, J. A., Niklaus, M., Beeching, J. R., Gruissem, W., and Vanderschuren, H. (2009). Agrobacterium-mediated transformation of friable embryogenic calli and regeneration of transgenic cassava. Nat. Protoc. 4, 1845-1854. doi: 10.1038/nprot.2009.208

Bull, S. E., Seung, D., Chanez, C., Mehta, D., Kuon, J.-E., Truernit, E., et al. (2018). Accelerated ex situ breeding of GBSS- and PTST1-edited cassava for modified starch. Sci. Adv. 4:eaat6086. doi: 10.1126/sciadv.aat6086

Burns, A., Gleadow, R., Cliff, J., Zacarias, A., and Cavagnaro, T. (2010). Cassava: the drought, war and famine crop in a changing world. Sustainability 2:3572. doi: 10.3390/su2113572

Ceballos, H., Iglesias, C. A., Pérez, J. C., and Dixon, A. G. O. (2004). Cassava breeding: opportunities and challenges. Plant Mol. Biol. 56, 503-516. doi: 10.1007/s11103-004-5010-5

Chauhan, R. D., Beyene, G., Kalyaeva, M., Fauquet, C. M., and Taylor, N. (2015). Improvements in agrobacterium-mediated transformation of cassava (Manihot esculenta Crantz) for large-scale production of transgenic plants. Plant Cell Tissue Organ Cult. 121, 591-603. doi: 10.1007/s11240-015-0729-z

Chauhan, R. D., Beyene, G., and Taylor, N. J. (2018). Multiple morphogenic culture systems cause loss of resistance to cassava mosaic disease. BMC Plant Biol. 18:132. doi: 10.1186/s12870-018-1354-x

Chetty, C. C., Rossin, C. B., Gruissem, W., Vanderschuren, H., and Rey, M. E. (2013). Empowering biotechnology in southern Africa: establishment of a robust transformation platform for the production of transgenic industrypreferred cassava. N. Biotechnol. 30, 136-143. doi: 10.1016/j.nbt.2012.04.006

Danso, K. E., Elegba, W. K., Oduro, V. B., and Kpentey, P. B. (2010). Comparative study of 2,4-D and Picloram on friable embryogenic calli and somatic embryos development in cassava (Manihot esculenta Crantz). Int. J. Integr. Biol. 10, 94-100.

Danso, K., and Ford-Lloyd, B. (2002). Induction of high-frequency somatic embryos in cassava for cryopreservation. Plant Cell Rep. 21, 226-232. doi: 10.1007/s00299-002-0516-2

Doyle, J. J. (1990). Isolation of plant DNA from fresh tissue. Focus 12, 13-15.

Ekeleme, F., Atser, G., Dixon, A., Hauser, S., Chikoye, D., Olorunmaiye, P. M., et al. (2019). Assessment of weeds of cassava and farmers' management practices in Nigeria. Tropicultura 37:12. doi: 10.25518/2295-8010.586

Elegba, W., Gruissem, W., and Vanderschuren, H. (2020). Screening for resistance in farmer-preferred cassava cultivars from Ghana to a mixed infection of CBSV and UCBSV. Plants 9:1026. doi: 10.3390/plants9081026

Elhiti, M., Stasolla, C., and Wang, A. (2013). Molecular regulation of plant somatic embryogenesis. Vitro Cell. Dev. Biol. Plant 49, 631-642. doi: 10.1007/ s11627-013-9547-3
El-Sharkawy, M. A. (2006). International research on cassava photosynthesis, productivity, eco-physiology, and responses to environmental stresses in the tropics. Photosynthetica 44, 481-512. doi: 10.1007/s11099-006-0063-0

Ezezika, O. C., Daar, A. S., Barber, K., Mabeya, J., Thomas, F., Deadman, J., et al. (2012). Factors influencing agbiotech adoption and development in sub-Saharan Africa. Nat. Biotechnol. 30, 38-40. doi: 10.1038/nbt.2088

FAO (2013). Save and Grow: Cassava. A Guide to Sustainable Production Intensification. Rome: FAO.

Fregene, M., Angel, F., Gomez, R., Rodriguez, F., Chavarriaga, P., Roca, W., et al. (1997). A molecular genetic map of cassava (Manihot esculenta Crantz). Theor. Appl. Genet. 95, 431-441. doi: 10.1007/s001220050580

Fregene, M., Bernal, A., Duque, M., Dixon, A., and Tohme, J. (2000). AFLP analysis of African cassava (Manihot esculenta Crantz) germplasm resistant to the cassava mosaic disease (CMD). Theor. Appl. Genet. 100, 678-685. doi: $10.1007 / \mathrm{s} 001220051339$

Fregene, M., Morante, N., Sánchez, T., Marín, J. A., Ospina, C., Barrera, E., et al. (2006). Molecular markers for introgression of useful traits from wild Manihot relatives of cassava, marker-assisted selection (MAS) of disease and root quality traits. J. Root Crops 32, 1-31.

González, A. E., Schöpke, C., Taylor, N. J., Beachy, R. N., and Fauquet, C. M. (1998). Regeneration of transgenic cassava plants (Manihot esculenta Crantz) through agrobacterium-mediated transformation of embryogenic suspension cultures. Plant Cell Rep. 17, 827-831. doi: 10.1007/s002990050492

Gresshoff, P. M., and Doy, C. H. (1974). Derivation of a haploid cell line from Vitis vinifera and the importance of the stage of meiotic development of anthers for haploid culture of this and other genera. Z. Pflanzenphysiol. 73, 132-141. doi: 10.1016/S0044-328X(74)80084-X

Hahn, S. K., Isoba, J. C. G., and Ikotun, T. (1989). Resistance breeding in root and tuber crops at the international institute of tropical agriculture (IITA), Ibadan, Nigeria. Crop Prot. 8, 147-168. doi: 10.1016/0261-2194(89)90022-7

Hankoua, B. B., Ng, S. Y. C., Fawole, I., Puonti-Kaerlas, J., Pillay, M., and Dixon, A. G. O. (2005). Regeneration of a wide range of African cassava genotypes via shoot organogenesis from cotyledons of maturing somatic embryos and conformity of the field-established regenerants. Plant Cell Tissue Organ Cult. 82, 221-231. doi: 10.1007/s11240-005-0514-5

Hankoua, B., Taylor, N. J., Ng, S. Y. C., Fawole, I., Puonti-Kaerlas, J., Padmanabhan, C., et al. (2006). Production of the first transgenic cassava in Africa via direct shoot organogenesis from friable embryogenic calli and germination of maturing somatic embryos. Afr. J. Biotechnol. 5, 1700-1712.

Ihemere, U. (2003). Somatic embryogenesis and transformation of cassava for enhanced starch production. Ohio State University.

Ihemere, U., Arias-Garzon, D., Lawrence, S., and Sayre, R. (2006). Genetic modification of cassava for enhanced starch production. Plant Biotechnol. J. 4, 453-465. doi: 10.1111/j.1467-7652.2006.00195.x

Jennings, D. L., and Iglesias, C. (2002). "Breeding for cop improvement," in Cassava: Biology, Production and Utilization. eds. R. J. Hillocks, J. M. Thresh and A. C. Bellotti (New York: CABI publishers), 149-166

Jorgensen, K., Bak, S., Busk, P. K., Sorensen, C., Olsen, C. E., Puonti-Kaerlas, J., et al. (2005). Cassava plants with a depleted cyanogenic glucoside content in leaves and tubers. Distribution of cyanogenic glucosides, their site of synthesis and transport, and blockage of the biosynthesis by RNA interference technology. Plant Physiol. 139, 363-374. doi: 10.1104/pp.105.065904

Kaeppler, S. M., Kaeppler, H. F., and Rhee, Y. (2000). Epigenetic aspects of somaclonal variation in plants. Plant Mol. Biol. 43, 179-188. doi: 10.1023/ a:1006423110134

Kawano, K. (2003). Thirty years of cassava breeding for productivity-biological and social factors for success. Crop Sci. 43, 1325-1335. doi: 10.2135/cropsci2003. 1325

Konan, N. K., Sangwan, R. S., and Sangwan-Norreel, B. S. (1994). Efficient in vitro shoot-regeneration systems in cassava (Manihot esculenta Crantz). Plant Breed. 113, 227-236. doi: 10.1111/j.1439-0523.1994.tb00727.x

Legg, J. P., Jeremiah, S. C., Obiero, H. M., Maruthi, M. N., Ndyetabula, I. Okao-Okuja, G., et al. (2011). Comparing the regional epidemiology of the cassava mosaic and cassava brown streak virus pandemics in Africa. Virus Res. 159, 161-170. doi: 10.1016/j.virusres.2011.04.018

Legg, J. P., Kumar, P. L., and Makeshkumar, T., L. Tripathi, Ferguson, M., Kanju, E., et al. (2015). Cassava virus diseases: biology, epidemiology, and management. Adv. Virus Res. 91, 85-142. doi:10.1016/bs.aivir.2014.10.001 
Lentz, E. M., Eisner, S., McCallum, E. J., Schlegel, K., Campos, F. A. P., Gruissem, W., et al. (2018). Genetic transformation of recalcitrant cassava by embryo selection and increased hormone levels. Methods Protoc. 1:42. doi: 10.3390/mps1040042

Li, K. T., Moulin, M., Mangel, N., Albersen, M., Verhoeven-Duif, N. M., Ma, Q., et al. (2015). Increased bioavailable vitamin B6 in field-grown transgenic cassava for dietary sufficiency. Nat. Biotechnol. 33, 1029-1032. doi: 10.1038/nbt.3318

Li, H.-Q., Sautter, C., Potrykus, I., and Puonti-Kaerlas, J. (1996). Genetic transformation of cassava (Manihot esculenta Crantz). Nat. Biotechnol. 14, 736-740. doi: 10.1038/nbt0696-736

Liu, J., Zheng, Q., Ma, Q., Gadidasu, K. K., and Zhang, P. (2011). Cassava genetic transformation and its application in breeding. J. Integr. Plant Biol. 53, 552-569. doi: 10.1111/j.1744-7909.2011.01048.x

Luong, H. T., Shewry, P. R., and Lazzeri, P. A. (1995). Transient gene expression in cassava somatic embryos by tissue electroporation. Plant Sci. 107, 105-115. doi: 10.1016/0168-9452(95)04101-Y

Ma, Q., Zhou, W., and Zhang, P. (2015). Transition from somatic embryo to friable embryogenic callus in cassava: dynamic changes in cellular structure, physiological status, and gene expression profiles. Front. Plant Sci. 6:824. doi: 10.3389/fpls.2015.00824

Manu-Aduening, J. A., Lamboll, R. I., Mensah, G. A., Lamptey, J. N., Moses, E., Dankyi, A. A., et al. (2006). Development of superior cassava cultivars in Ghana by farmers and scientists: the process adopted, outcomes and contributions and changed roles of different stakeholders. Euphytica 150, 47-61. doi: 10.1007/s10681-006-9091-x

Miguel, C., and Marum, L. (2011). An epigenetic view of plant cells cultured in vitro: somaclonal variation and beyond. J. Exp. Bot. 62, 3713-3725. doi: 10.1093/jxb/err155

Narayanan, N., Beyene, G., Chauhan, R. D., Gaitán-Solís, E., Gehan, J., Butts, P., et al. (2019). Biofortification of field-grown cassava by engineering expression of an iron transporter and ferritin. Nat. Biotechnol. 37, 144-151. doi: 10.1038/ s41587-018-0002-1

Narayanan, N., Beyene, G., Chauhan, R. D., Grusak, M. A., and Taylor, N. J. (2020). Stacking disease resistance and mineral biofortification in cassava varieties to enhance yields and consumer health. Plant Biotechnol. J. 19, 844-854. doi: 10.1111/pbi.13511

Nassar, N. M., Hashimoto, D. Y., and Fernandes, S. D. (2008). Wild Manihot species: botanical aspects, geographic distribution and economic value. Genet. Mol. Res. 7, 16-28. doi: 10.4238/vol7-1gmr389

Nassar, N., and Ortiz, R. (2010). Breeding cassava to feed the poor. Sci. Am. 302, 78-84. doi: 10.1038/scientificamerican0510-78

Nowack, M. K., Grini, P. E., Jakoby, M. J., Lafos, M., Koncz, C., and Schnittger, A. (2006). A positive signal from the fertilization of the egg cell sets off endosperm proliferation in angiosperm embryogenesis. Nat. Genet. 38, 63-67. doi: 10.1038/ng1694

Nyaboga, E., Njiru, J., Nguu, E., Gruissem, W., Vanderschuren, H., and Tripathi, L. (2013). Unlocking the potential of tropical root crop biotechnology in East Africa by establishing a genetic transformation platform for local farmerpreferred cassava cultivars. Front. Plant Sci. 4:526. doi: 10.3389/fpls.2013.00526

Nyaboga, E., Njru, J. M., and Tripathi, L. (2015). Factors influencing somatic embryogenesis, regeneration, and agrobacterium-mediated transformation of cassava (Manihot esculenta Crantz) cultivar TME14. Front. Plant Sci. 6:411. doi: $10.3389 /$ fpls.2015.00411

Ojola, P. O., Nyaboga, E. N., Njiru, P. N., and Orinda, G. (2018). Overexpression of rice thaumatin-like protein (Ostlp) gene in transgenic cassava results in enhanced tolerance to Colletotrichum gloeosporioides f. sp. manihotis. J. Genet. Eng. Biotechnol. 16, 125-131. doi: 10.1016/j.jgeb.2017.12.002

Okogbenin, E., Egesi, C., Olasanmi, B., Ogundapo, O., Kahya, S. S., Hurtado, P., et al. (2012). Molecular marker analysis and validation of resistance to cassava mosaic disease in elite cassava genotypes in Nigeria. Crop Sci. 52:2576. doi: 10.2135/cropsci2011.11.0586

Orek, C., Gruissem, W., Ferguson, M., and Vanderschuren, H. (2020). Morphophysiological and molecular evaluation of drought tolerance in cassava (Manihot esculenta Crantz). Field Crop Res. 255:107861. doi: 10.1016/j.fcr.2020.107861

Patil, B. L., and Fauquet, C. M. (2009). Cassava mosaic geminiviruses: actual knowledge and perspectives. Mol. Plant Pathol. 10, 685-701. doi: 10.1111/j. 1364-3703.2009.00559.x

Patil, B. L., Legg, J. P., Kanju, E., and Fauquet, C. M. (2015). Cassava brown streak disease: a threat to food security in Africa. J. Gen. Virol. 96, 956-968. doi: $10.1099 /$ jgv.0.000014
Pretova, A., and Williams, E. G. (1986). Direct somatic embryogenesis from immature zygotic embryos of flax (Linum usitatissimum L.). J. Plant Physiol. 126, 155-161. doi: 10.1016/S0176-1617(86)80016-5

Rabbi, I. Y., Hamblin, M. T., Kumar, P. L., Gedil, M. A., Ikpan, A. S., Jannink, J. L., et al. (2014). High-resolution mapping of resistance to cassava mosaic geminiviruses in cassava using genotyping-by-sequencing and its implications for breeding. Virus Res. 186, 87-96. doi: 10.1016/j.virusres.2013.12.028

Raemakers, K., Schreuder, M., Pereira, I., Munyikwa, T., Jacobsen, E., and Visser, R. (2001). Progress made in FEC transformation of cassava. Euphytica 120, 15-24. doi: 10.1023/a:1017574713880

Rey, C., and Vanderschuren, H. V. (2017). Cassava mosaic and brown streak diseases: current perspectives and beyond. Annu. Rev. Virol. 4, 429-452. doi: 10.1146/annurev-virology-101416-041913

Rossin, C. B., and Rey, M. E. C. (2011). Effect of explant source and auxins on somatic embryogenesis of selected cassava (Manihot esculenta Crantz) cultivars. S. Afr. J. Bot. 77, 59-65. doi: 10.1016/j.sajb.2010.05.007

Schöpke, C., Chavarriaga, P., Mathews, H., Lic, G., Fauquet, C., and Beachy, R. N. (1993). Transformation of cassava (Manihot esculenta Crantz) somatic embryos using particle bombardment. Paper presented at the Congress on CCLL and Tissue Culture, San Diego.

Schöpke, C., Taylor, N., Cárcamo, R., Konan, N. K., Marmey, P., Henshaw, G. G., et al. (1996). Regeneration of transgenic cassava plants (Manihot esculenta Crantz) from microbombarded embryogenic suspension cultures. Nat. Biotechnol. 14, 731-735. doi: 10.1038/nbt0696-731

Schreuder, M. M., Raemakers, C. J. J. M., Jacobsen, E., and Visser, R. G. F. (2001). Efficient production of transgenic plants by agrobacterium-mediated transformation of cassava (Manihot esculenta Crantz). Euphytica 120, 35-42. doi: 10.1023/a:1017530932536

Siritunga, D., and Sayre, R. (2003). Generation of cyanogen-free transgenic cassava. Planta 217, 367-373. doi: 10.1007/s00425-003-1005-8

Stroud, H., Ding, B., Simon, S. A., Feng, S., Bellizzi, M., Pellegrini, M., et al. (2013). Plants regenerated from tissue culture contain stable epigenome changes in rice. eLife 2:e00354. doi: 10.7554/eLife.00354

Taylor, N., Chavarriaga, P., Raemakers, K., Siritunga, D., and Zhang, P. (2004). Development and application of transgenic technologies in cassava. Plant Mol. Biol. 56, 671-688. doi: 10.1007/s11103-004-4872-x

Taylor, N. J., Edwards, M., Kiernan, R. J., Davey, C. D. M., Blakesley, D., and Henshaw, G. G. (1996). Development of friable embryogenic callus and embryogenic suspension culture systems in cassava (Manihot esculenta Crantz). Nat. Biotechnol. 14, 726-730. doi: 10.1038/nbt0696-726

Taylor, N., Gaitán-Solís, E., Moll, T., Trauterman, B., Jones, T., Pranjal, A., et al. (2012). A high-throughput platform for the production and analysis of transgenic cassava (Manihot esculenta) plants. Trop. Plant Biol. 5, 127-139. doi: 10.1007/s12042-012-9099-4

Thorpe, T. A. (2006). History of plant tissue culture. Methods Mol. Biol. 318, 9-32. doi: 10.1385/1-59259-959-1:009

Vandegeer, R., Miller, R., Bain, M., Gleadow, R., and Cavagnaro, T. R. (2013). Drought adversely affects tuber development and nutritional quality of the staple crop cassava (Manihot esculenta Crantz). Funct. Plant Biol. 40, 195-200. doi: 10.1071/FP12179

Vanderschuren, H. (2012). Strengthening African R\&D through effective transfer of tropical crop biotech to African institutions. Nat. Biotechnol. 30, 1170-1172. doi: $10.1038 /$ nbt.2405

Vanderschuren, H., Alder, A., Zhang, P., and Gruissem, W. (2009). Dosedependent RNAi-mediated geminivirus resistance in the tropical root crop cassava. Plant Mol. Biol. 70, 265-272. doi: 10.1007/s11103-009-9472-3

Vanderschuren, H., Moreno, I., Anjanappa, R. B., Zainuddin, I. M., and Gruissem, W. (2012). Exploiting the combination of natural and genetically engineered resistance to cassava mosaic and cassava brown streak viruses impacting cassava production in Africa. PLoS One 7:e45277. doi: 10.1371/journal.pone.0045277

Vanderschuren, H., Nyaboga, E., Poon, J. S., Baerenfaller, K., Grossmann, J., Hirsch-Hoffmann, M., et al. (2014). Large-scale proteomics of the cassava storage root and identification of a target gene to reduce postharvest deterioration. Plant Cell 26, 1913-1924. doi: 10.1105/tpc.114.123927

Vindeløv, L. L., Christensen, I. J., Jensen, G., and Nissen, N. I. (1983). Limits of detection of nuclear DNA abnormalities by flow cytometric DNA analysis. Results obtained by a set of methods for sample-storage, staining and internal standardization. Cytometry 3, 332-339. doi: 10.1002/cyto.990030505

Walsh, H. A., Vanderschuren, H., Taylor, S., and Rey, M. E. C. (2019). RNA silencing of south African cassava mosaic virus in transgenic cassava expressing 
AC1/AC4 hp-RNA induces tolerance. Biotechnol. Rep. 24:e00383. doi: 10.1016/j. btre.2019.e00383

Zaidi, S. S.-E.-A., Vanderschuren, H., Qaim, M., Mahfouz, M. M., Kohli, A., Mansoor, S., et al. (2019). New plant breeding technologies for food security. Science 363, 1390-1391. doi: 10.1126/science.aav6316

Zainuddin, I. M., Schlegel, K., Gruissem, W., and Vanderschuren, H. (2012). Robust transformation procedure for the production of transgenic farmerpreferred cassava landraces. Plant Methods 8:24. doi: 10.1186/1746-4811-8-24

Zhang, P., and Gruissem, W. (2004). "Production of transgenic cassava (Manihot esculenta Crantz)," in Transgenic Crops of the World: Essential Protocols. ed. I. S. Curtis (Dordrecht, Netherlands: Springer), 301-319.

Zhang, P., Legris, G., Coulin, P., and Puonti-Kaerlas, J. (2000). Production of stably transformed cassava plants via particle bombardment. Plant Cell Rep. 19, 939-945. doi: 10.1007/s002990000224

Zhang, P., and Puonti-Kaerlas, J. (2000). PIG-mediated cassava transformation using positive and negative selection. Plant Cell Rep. 19, 1041-1048. doi: 10.1007/s002990000245
Zhang, P., Vanderschuren, H., Futterer, J., and Gruissem, W. (2005). Resistance to cassava mosaic disease in transgenic cassava expressing antisense RNAs targeting virus replication genes. Plant Biotechnol. J. 3, 385-397. doi: 10.1111/j. 1467-7652.2005.00132.x

Conflict of Interest: The authors declare that the research was conducted in the absence of any commercial or financial relationships that could be construed as a potential conflict of interest.

Copyright (c) 2021 Elegba, McCallum, Gruissem and Vanderschuren. This is an open-access article distributed under the terms of the Creative Commons Attribution License (CC BY). The use, distribution or reproduction in other forums is permitted, provided the original author(s) and the copyright owner(s) are credited and that the original publication in this journal is cited, in accordance with accepted academic practice. No use, distribution or reproduction is permitted which does not comply with these terms. 